\title{
The market for films in postwar Italy: evidence for both national and regional patterns of taste
}

Article

Accepted Version

Sedgwick, J., Miskell, P. and Nicoli, M. (2019) The market for films in postwar Italy: evidence for both national and regional patterns of taste. Enterprise and Society, 20 (1). pp. 199-228. ISSN 1467-2235 doi: https://doi.org/10.1017/eso.2018.22 Available at https://centaur.reading.ac.uk/77189/

It is advisable to refer to the publisher's version if you intend to cite from the work. See Guidance on citing.

To link to this article DOI: http://dx.doi.org/10.1017/eso.2018.22

Publisher: Cambridge University Press

All outputs in CentAUR are protected by Intellectual Property Rights law, including copyright law. Copyright and IPR is retained by the creators or other copyright holders. Terms and conditions for use of this material are defined in the End User Agreement.

www.reading.ac.uk/centaur 
Central Archive at the University of Reading

Reading's research outputs online 


\section{The post-war Italian film market: evidence for both national and regional patterns of taste}

John Sedgwick, Peter Miskell and Marina Nicoli

\section{Abstract}

The post-war market for films in Italy resembles those found in other developed capitalist economies, in which supply adjusts to demand through a set of institutional arrangements designed to maximize revenue for the film distributor. The outcome is a statistical distribution of revenues that manifests extreme levels of inequality, indicating that the hits of the day were 'giants' in relation to the median film and enjoyed throughout the territory. By drawing upon film industry sourced box-office data for five cities, Milan and Turin in the North; Naples and Bari in the South and Rome in the centre, the market mechanism can be observed operating at the city level, allowing the exploration of differences in preferences between the cities. A Relative Popularity Index (RelPOP) is introduced to measure variation in film popularity across the five cities and clear evidence is found to support the co-existence of national and local taste. This phenomenon is examined with respect to those films that were exceptionally popular throughout, and those with particular geographically specific audiences. The example of the many films that starred Totò, appealing in particular to South Italian audiences, is highlighted and contrasted with the Don Camillo series of films that were set in Emilia Romagna and which appealed differentially to filmgoers in the North. 


\section{Introduction}

The international distribution of cultural products and their reception in local markets is a matter that straddles the domains of business, economics and cultural studies. As an example of a recorded entertainment commodity, film can be replicated at little or no additional cost, encouraging as wide an international distribution as possible. Yet the cultural properties of film as an aesthetic artefact make the task of finding, and satisfying, a global audience more troublesome. As one economic study of the international film industry puts it: '...cultural products are intimately bound up with matters of selfhood, identity and consciousness... each individual's consumption of cultural products is replete with externalities for all other individuals in the same society. Politicised responses to the flow of cultural products from one society to another are therefore to be expected.'1 Thus, although once produced, films can technically be made available everywhere at minimal marginal cost, consumers and regulators may have no wish accept them. As a consequence, film producers in most countries have struggled to reach international audiences.

Broadly speaking, explanations for the difficulties faced by film producers in reaching international audiences fall into two categories: a demand-side explanation, emphasising the distinct tastes and preferences of audiences (consumers) in different countries; and a supply-side perspective, highlighting barriers or constraints limiting free access markets for foreign-made cultural products. Untangling these two effects can be very difficult. Do foreign products fail to find a foothold in domestic markets because audiences reject them in favour of locally produced content, or because these products are not easily 
accessible to local audiences in the first place? Most studies up to the present have treated national markets as homogeneous. In this article we examine the possibility that different audiences in different regional centres with different cultural traditions, have different preferences. By focusing analysis at the subnational level, differences in consumer preferences between specific cities or regions cannot be explained by national level policies designed to influence supply flows, such as quotas, tariffs or tax incentives, leaving us in a better position to separate these differences for analytical purposes. The film industry is a particularly apt for this purpose because differences in quality are not reflected in differences in price, meaning income or substitution effects are not discernable in consumer behaviour.

Many existing explanations for the remarkable international success achieved by Hollywood entertainment have emphasised the roles played by firms and US government departments in overcoming barriers to entry to foreign markets. ${ }^{2}$ The activities of the US State Dept. and the Dept. of Trade in pressuring foreign governments to open up their markets to US film imports, feature prominently in these accounts. So too does the expansion of international distribution by US firms, with the major American producer-distributors operating extensive networks of distribution offices by the $1920 \mathrm{~s}^{3}$ The extent to which audiences in these foreign markets genuinely preferred Hollywood entertainment to locally produced content is not so easy to determine. Gerben Bakker has certainly demonstrated that film production budgets in the United States escalated rapidly in the 1910s, enabling US producers to take an unassailable lead over European rivals in the so-called 'quality race'4. Similarly, Peter Miskell has shown that US 
firms during the studio era built into their production portfolios a proportion of films apparently designed to appeal specifically to international audiences. ${ }^{5}$

Clearly, throughout its history Hollywood has produced films designed to attract a widespread international popular audience. The films of Greta Garbo for MGM during the 1930s are a famous example of this strategy. ${ }^{6}$ But not all films emanating from Hollywood were as equally attractive to foreign audiences and outperformed home produced films.

Set against the success of Hollywood in international markets is the knowledge that outside of the US, indigenous production, often manifesting much poorer technical qualities, has captured significant market share in its home market. In his study of the small interwar French company Les Film Albertros, Gerben Bakker shows that in order for such firms to survive they had to produce low cost films of sufficient quality necessary to attract the size of audience that allowed cinema owners to cover their fixed costs. ${ }^{7}$ Empirical studies of the Australian, British, and Dutch markets in the 1930s and Italian market in the mid 1950s, show that in each home produced films could be extremely popular with audiences. ${ }^{8}$ Yet, as Joseph Garncarz has shown for the first half of the1930s, while very few French and British films were popular in Germany, or German and British films in France, or French and German films in the UK, the American product was ubiquitous. Hollywood, as Richard Kuisel puts it, was 'everyone's second culture.'9

The picture that emerges from this literature is the presence, since at least the 1930s, of two distinct categories of popular cinema. On the one side we have an 
internationally oriented mode of production, centred in Hollywood, which conceived its audience as a global one. On the other, a series of 'national cinemas', often defined against a Hollywood 'other', with a deeper but narrower domestic appeal. This phenomenon links to two related swathes of literature around the banners of 'cultural distance' and the 'liability of foreignness'.10 In short, Hollywood worked assiduously (and often effectively) to overcome liabilities of foreignness, while national cinemas operated firmly within these confines.

But just how 'national' were national cinema industries outside the United States? A number of studies have indicated that the output of leading national producers was often more popular in metropolitan centres than in provincial or suburban areas. ${ }^{11}$ This article will examine not just the popularity of films in different regional locations, but also whether identifiably different types of films were developed for specific regional audiences.

One way of thinking about the choices made by film consumers is to distinguish between products that are horizontally and vertically differentiated. ${ }^{12}$ Films are horizontally differentiated by means of their characteristics, so that when positioned along a continuum near neighbours are placed close to one another. Film genres are example of horizontal differentiation; the national origins of film are another; types of star are a third, each offering a mechanism by which consumers can readily categorise cultural products, allowing them one means of navigating what Richard Caves refers to as the 'infinite variety' of choice available. ${ }^{13}$ In contrast, films that are differentiated vertically are widely 
recognised by consumers as being qualitatively better: some are preferred to others, hence the highly skewed distribution of revenues generated by the films released in any given market. ${ }^{14}$ Whereas horizontal differentiation is something that can be shaped and controlled by film producers and distributors - for instance, films can be quite deliberately marketed as 'horror' or 'sci-fi' movies vertical differentiation is determined by the reaction of audiences and far less predictable. Neither producers, nor consumers, can really know in advance whether films will be hits or flops, hence the well worn industry mantra that 'nobody knows anything'.

Studying variations in the reception of different types of film at the sub-national level allows for an exploration of both horizontal and vertical forms of differentiation. It is possible to identify which films were disproportionately popular, or unpopular, in each city and make comparisons. Furthermore, from this empirical base audience preferences for certain 'types' of horizontally differentiated products can be established. In other words, we can observe whether there was a mode of 'regional' production to add to the well-established categories of 'national' and 'international' films.

Drawing upon evidence from the Italian market in the post-war era, this article investigates film consumer choice by means of an analysis of city box-office data, specifically for the 10 seasons $1957-8$ to $1966-7$. The selected cities and regional capitals are Rome in the centre, Milan and Turin in the North and Naples and Bari in the South. In particular, the focus is on how consumer preferences varied according to location and with this the extent to which the Italian film market 
was really a national one, or rather a series of distinct regional markets. As a consequence, among other things, the analysis will shed light on regional differences in the demand for home and Hollywood produced films.

\section{Context}

This was a period during which the so-called 'Italian Miracle' was in full swing, during which per capita income and living standards in Italy grew dramatically, doubling between the mid-1950s and 60s during which the historical divide between the South and North narrowed. ${ }^{15}$ The role of mass culture in the process has been well documented by David Forgacs and Stephen Gundle, who write: '...mass culture set in motion two processes that worked in opposing directions during the period under analysis. First, certain media products - radio programs, recorded music, cinema, news reels, magazine photographs - helped make Italian society more visible and audible to its members...Second, the media and mass culture put in circulation words and sounds from other societies and these fuelled private aspirations and desires, changed perceptions of what were deemed acceptable secular behaviour and gender roles and drove wedges between generations, helping to create new social demarcations.' (Forgacs and Gundle, 2007, p.2)

The period witnessed the resurgence in domestic Italian film production, including a rapid growth in the number of international co-productions between European producers. ${ }^{16}$ Furthermore, the impact of television as a substitute good was less pronounced in Italy during these years, with the diffusion rate in 1966 
still less than half of all households. ${ }^{17}$ Indeed, an international comparison shows that in Italy in 1965 there were 12 televisions for every 100 inhabitants, in contrast to 25 in the Great Britain, 19 in Germany and 13 in France. ${ }^{18}$

\section{[Table 1 here]}

Dominating all other entertainments, Table 1 shows that film audiences in Italy peaked in the mid-1950s, some 10 years after the UK and US, and remained relatively stable until at least the mid-1960s. ${ }^{19}$ Indeed, the dramatic decline in attendance seen in the US, UK and elsewhere in the 1950s and 1960s did not occur in Italy until the 1970s. The Italian market therefore became increasing important to American distributors, as well as to other European producers.

'Film distribution in Italy during this period was typically organised either by domestic Italian companies - of which we identify 59 in total - or by local subsidiaries of the seven major American distributors. There were a small number of Italian-American distribution joint ventures, but such partnerships offered more obvious benefits to American firms than local ones, and only two such collaborations were really enduring. ${ }^{20}$ While there is some evidence that local distributors were more effective than foreign ones at maximising screen time for the most successful pictures, there is no evidence that distributors routinely offered different rental terms for their pictures. Rental prices were negotiated nationally by industry bodies representing exhibitors (AGIS) and distributors (ANICA) and applied equally to American and Italian firms. All American distributors, and all but two of the Italian ones, operated on a national basis releasing pictures through 16 distribution hubs in major cities throughout 
the country. ${ }^{21}$ We have no reason to believe, therefore, that any regional variations in demand would have been created by supply-side distortions.'

\section{Box-office characteristics}

Over the 10-year period between 454 and 617 films were released annually on the market with Italian film producers responsible for approximately a quarter of releases in 1957, rising to a half by 1966. During these years co-productions increasingly came to dominate domestic production. Indeed, in 1966143 films were co-produced compared to 89 solo home productions. ${ }^{22}$ Overall, it is clear that Italian film consumers had a plethora of films to choose between.

The most important source of statistical evidence about the revenues generated by films circulating in Italian cities during these years was located in the section Borsa Film found in the twice monthly trade publication Giornale dello Spettacolo - an official trade publication, sponsored by the national association of exhibitors (AGIS). Along with commentaries on the performance of films in the Italian market, for the 10 years of this study Borsa Film published first-run box-office records of sixteen Italian cities that served as regional distribution centres. ${ }^{23}$

Selecting 1962 as a typical year, in which 551 films were in circulation, statistics of the five cities chosen for analysis are the subject of Table 2. Drawn from records collected by the Italian Society of Authors and Publishers (SIAE) and published in their annual publication Annuario dello Spettacolo, it is evident from Table 2 that the size of market (by value), cinema admission prices and per capita cinema expenditure varied from city to city, but were considerably lower 
the Southern cities, reflecting the large discrepancy in GDP per capita between southern Italy and the northern and central regions, reflecting the large discrepancy in GDP per capita between southern Italy and the northern and central regions. ${ }^{24}$

However, it is also noteworthy that ticket sales per capita in Naples and Bari did not lag that far behind those of Rome, Milan and Turin. Thus, although the economic circumstances of film consumption may have differed city-to-city, the appetite for films was more uniform. ${ }^{25}$

\section{[Table 2 here]}

First analysed in detail by Arthur De Vany and David Walls, the film market is characterised by highly unequal revenue distributions that generate very high gini-coefficients. ${ }^{26}$ In their comparative study of British and US film markets during the mid-1930s John Sedgwick and Michael Pokorny found that the mean and median film revenues both fell into the first decile of the revenue distribution. ${ }^{27}$ It would appear that the long right tail phenomenon is an empirical regularity in film markets across all territories and over time, a factor that has given rise to the particular supply arrangements that characterise the industry, designed to ensure that distributors maximise revenues by making films that are popular ubiquitous. Film (like music, book publishing or video game production) can be described as a 'hits-based' industry. ${ }^{28}$

\section{[Figure 1 here]}

Arbitrarily selecting the top 50 films for the season 1961-2, Figure 1 reveals aspects of this phenomenon within the Italian market at the city-level. (Because the films taking up these top berths were in many cases similarly popular across the five cities, aggregating earnings within a territory will accentuate both the 
steepness of the decline and the comparative flatness of the tail of the rank revenue distribution.) In Figure 1, typically, a sharp drop in box office revenue can be noticed between the first and the fifth ranked films, followed by a further significant drop to the tenth ranked film, before the curve starts to flatten out to form a long tail beyond the 50 film limit in Figure 1. While the basic distribution of box office revenues follows a broadly similar pattern in each city, it is evident that the overall size of these markets was very different and that the smaller the market the relatively flatter the distribution: smaller markets are less able to fuel major film attractions with audiences. Thus, the top ranked film in the largest markets of Rome and Milan collected far more revenue than in Naples or Turin, and these markets were in turn much more lucrative than Bari. The highest earning film in Bari generated approximately the same amount of revenue as the 6th ranked film in Naples, 25th film in Turin, 68th ranked film in Milan and 75th ranked film in Rome. 
Unfortunately, the city-based box-office data drawn from Giornale dello

Spettacolo upon which Figure 1 and the remainder of the article is formed is restricted to first-run markets, clearly limiting what can be said about film consumer behaviour. Nevertheless, while not providing definitive evidence on film performance in these cities, previous studies indicate that it is highly likely that the films that achieved the largest market share in first-run markets would also have been widely distributed in second and third run markets. ${ }^{29}$ Therefore, we are confident that our data offers a reliable means of identifying the most popular films in each of the regional capitals that forms this study.

\section{Comparative approach}

The absolute performance of films in different city markets poses a problem when it comes to comparing the popularity of films between cities. Simply comparing the box-office revenues of films gives little indication of the relative popularity of each film in each city. Such a comparison would no doubt reveal wide differences between the earnings of each film, but these would be driven by differences in market size as well as by variations in relative popularity. An alternative approach is to look at the annual rank of each film in each city. This at least allows us to identify the most popular films in each location, but while the rank ordering of films produces a neat linear pattern, as we have seen in Figure 1 , the actual distribution of film revenues is not linear at all. The difference in popularity between films ranked one and five is not comparable with that between films ranked 41 and 45, or for that matter even less so for ranks 101 and 105. 
To overcome this problem a metric has been constructed that captures the relative popularity of films, termed the Relative Popularity Index (RelPOP). ${ }^{30}$ In order to ensure that the films analysed were screened in each of the cities, a truncated sample of the 100 most popular films for each of the 10 cinema seasons from $1957 / 8$ to $1966 / 7$ have been selected, amounting to 1,000 films over the period. Given that as many as 600 films were released annually into these markets, many of which were screened in only a few cinemas, for only a few days, the sample clearly excludes large numbers of films. However, as an objective of this study is to compare the popularity of films, the selection of the top 100 films annually necessarily captures the most prominent new releases.

RelPOP is calculated by simply dividing the box office revenue of the focal film in each city by that of the box office earned by the median film (taken as the 51 st film in the annual city series). Thus, separate RelPOP scores are generated for films in each city market. Accordingly, a film with a RelPOP of 5 will have generated five times more revenue than the 51st film: a RelPOP of less than 1 indicates that the film was less popular than the 51st film. Taken together, over the five markets the mean RelPOP score (equation 1) of each film released constitutes an unweighted popularity series in which each city is treated equally, irrespective of market size. This can be then used to compare the popularity of films among the five cities, either separately or in total and the degree to which they vary: it is possible to say that Film $\mathrm{X}$ is more popular in Bari than in Turin, or that it is more popular in Bari than on average across the five cities, or that the variation in reception across the five cities is greater than that of Film Y. 
(1)... Re $l P O P_{i}={ }_{c=1}^{5} \frac{B O_{i c}}{B O_{m c}} 5$

where, $\mathrm{BO}=$ Box-office

$i=i$ th film

$c=c$ th city

$\mathrm{m}=$ median film

\section{[Table 3 here]}

By way of example Table 3 presents Top 10 results for the season 1966-67. The Notes section to the table guides the reader as to how the mean RelPOP and associated measures of variance are calculated. Even from this cross section a number of matters become apparent: the steep fall in mean RelPOP values with rank; the number of films that are commonly popular - overall top 10 films take up 38 of the possible 50 berths; the extraordinary performance of $\operatorname{Dr}$ Zhivago across the board but particularly in Turin, Naples and Bari; the relatively poor performance of the Bible: In the Beginning in Rome and Milan; set in Naples, the relatively poor performance of the Italian crime comedy The Treasure of San Gennaro in the Northern cities; the relatively strong performance of $A$ Man and $a$ Woman in Rome and Milan; the mediocre performance of the Taming of the Shrew in Milan; while a number of films including The Good, the Bad and the Ugly were universally popular generating low coefficient of variations values. 


\section{The Italian market}

The RelPOP metric provides many insights into the operation of the Italian film market. A simple process of correlating the RelPOP scores of films of each city with those of the other four cities is presented in Table 4 and shows a clear positive relationship in each case. ${ }^{31}$ On the whole we find that films at the bottom end of the distribution in one city, were also likely to be positioned toward the lower end in the other cities. Each season's major hits, meanwhile, were likely to be popular everywhere. If the existence of such clear positive relationships is unsurprising, it is perhaps more interesting to examine the strength of these relationships. Here we see some degree of variation, with extremely strong correlations between Rome and Milan (0.90) and Naples and Bari (0.86), but somewhat weaker relationships between Milan and Bari (0.51) or Milan and Naples (0.60).

[Table 4 here] 
Table 4 indicates the prevalence of variance in film popularity data between the five cities. Figure 2 makes this explicit by reporting the degree of variance with respect of the mean RelPOP values of the 1,000 films in the sample dataset set against their respective coefficients of determination.

\section{[Figure 2 here]}

Two observations are apparent from Figure 2 . The first is that even though the analysis is based on the 100 most popular films released annually into the Italian market, the revenue distribution exhibits a high degree of inequality, in which a small number of films generate extraordinarily box-office returns in relation to the median, with 26 films generating a RelPOP value of 5 or more; 18 of six or more; 12 of seven or more; and 11 of eight or more.

The second is that the coefficient of variation trends downwards in conjunction with popularity and thus typically the range of variance is lower among the most popular films. The biggest hits were indeed hits everywhere. It is among the slightly lower ranked films that second order variability - the variation in the coefficient of variation associated with films generating similar RelPOP values is more apparent, becoming more marked as the weight of the distribution is approached at the lower end of the RelPOP scale. Indeed, at the lower end of the distribution there is a roughly equal split between films above and below the trend line, suggesting that large numbers of films at this end of the spectrum were either commonly or unevenly attractive to audiences.

From these observations it is possible to surmise that the film market effectively distributed films to where audience wanted to see them, both in terms of extent 
and selectivity, supporting the conjecture that both vertical and horizontal product differentiation are evident: that is, a small number of films appear to be qualitatively superior to the rest, while the bulk of films attracted much smaller audiences, some consistently across the board but not others. Taken together with Table 4, we can conclude from this that Italy during this period showed evidence of being a receptive market in which hit films typically performed well in all markets, while regional variation - especially between cities in the north and south - was not uncommon, particularly at the lower end of the distribution.

\section{[Table 5 here]}

The national origin of the films that form the 1000 -film sample of this study is the subject of Table 5. Grouping co-productions under the first named national partner (Italian-French co-productions count as Italian films), Table 5 shows that the Italian market was dominated in almost equal part by films emanating from the studios of Hollywood and Cinecitta. As a rule, Italians were not drawn to the films made by French, German, British production companies, suggesting how segregated the European market was during this time.

\section{The film 'giants'}

Films that were extraordinarily popular are the 'giants 'of the business. They draw audiences many times that of the average. The extreme statistics associated with these films suggest that in addition to what Leo Handel categorized as regular and habitual filmgoers, they attract large numbers of occasional filmgoers to what is in effect a special event. ${ }^{32}$ Distributors and exhibitors feast on such films - distributors because of the higher rental percentages they can 
charge; exhibitors, because of the volume of customers passing through the boxoffice.

\section{[Table 6 here]}

Table 6 lists the 26 films that formed the right tail of the rank distribution found in Figure 2: films that generated at least five times median revenues. Among these are the ten annual number one films, while seven of the ten films ranked annually in second position are also represented in the table. However, beyond this, the annual pattern is varied, with the season 1964-5 having five films that garnered RelPOP values greater than five, while the seasons 1959-60, 1960-1, and 1961-2 had just one.

Although extremely wide ranging in content, production values, and budgets, the films in Table 6 are well represented by biblical, historical or literary epics, as well as adventures (wartime, or otherwise). Other traits that emerge are the emergence and of popularity of spaghetti westerns; the popularity of the James Bond movies; My Fair Lady is the only musical in the list and this set, incongruously, in Edwardian Britain; that two American comedies feature are listed - It's a Mad, Mad, Mad, Mad World and Some Like It Hot; and the only films in the list to depict the quotidian of everyday life are the comedy The Treasure of San Gennaro and two Italian melodramas Marriage Italian Style, and Yesterday, Today and Tomorrow, both directed by Vittorio de Sica, and starring Sophia Loren and Marcello Mastroianni. On the production side, with the exception of the latter three Italian films, all have an international dimension be that subject matter, star(s), and/or director. The national origins of these films indicate that 
big budget Hollywood and British productions (distributed and financed by American companies) coexist with Italian solo or co-production.

\section{Films which most divided audience opinion}

Central to this article is the issue concerning the differential performance of films within a single national territory. From the evidence presented in the scatter plot in Figure 2, a large body of films received variable attention from Italian audiences. In an efficient market this observation can be taken to indicate that audience tastes for some films differed noticeably from city to city and that supply adjusted to this. Evidence presented in Tables 3 and 4 supports this contention. An alternative hypothesis might be that differential performance is the consequence of institutional rigidities - for instance, distributors did not receive sufficient copies of some films in some cities to satisfy demand. For this to be the case, we should expect that in cities where among those films that performed poorly were a number of films for which daily box-office returns were similar to other films that had a much longer run. No evidence of this was found, implying that poorly performing films consistently generated lower daily boxoffice returns.

In order to identify a100 films that attracted particular local interest, two methods are followed. The simplest approach is to rank films by their coefficient of variation (CofV) value, and select the 100 most variably received films. This method certainly allows for the identification of films that performed strongly in just one city, but does not exclude other films that were relatively popular in two or three cities (and relatively unpopular in the others). Hence, if our interest is 
not just in the variability of a film's appeal, but in identifying those films with an appeal that seemed to be specific to just a single city, then an alternative approach is required. To this end we have also ranked films on the basis of how far their performance in any one of the five cities deviated from the average. This involved comparing each film's RelPOP score in each city, with its overall RelPOP score for the five cities combined, and searching for instances where the difference between the local and the overall RelPOP score was greatest. The 100 most variable films, on this basis, turned out to be ones in which the RelPOP score in one city was approximately 90 per cent higher than the overall RelPOP.

\section{[Table 7 here]}

Not surprisingly, there is a large amount of overlap between the two lists of 100 films generated by these competing methods. By way of explanation, some examples of films that appeared on one list, but not the other, are found in Table 7. The top two films on this list have a coefficient of variation score (just) high enough to make it into the top 100 on this measure, but in neither case is there a city RelPOP score that is 90 per cent higher than the overall RelPOP. The bottom two films, on the other hand, fall outside the top 100 when ranked by their coefficient of variation but generated RelPOP scores in a single city (Naples and Milan respectively) that were approximately 100 per cent higher than the overall RelPOP.

\section{[Table 8 here]}

Using each criteria, Table 8 presents a breakdown of the 100 most variable films, classified by: a) their national origin; and b) the city in which they were most popular. By grouping together Italian solo and co-productions, a comparison with Table 5 makes it clear that the representation of national productions 
among the most variably received films is markedly higher than in the sample population, with respectively 59 and 61 films being listed. It would appear that Italian films were much more likely to either excite local passions, or marked indifference, than their American counterparts.

When we look at the cities in which these films were most popular in Table 8, we also see consistency between the two lists. Roman audiences were the least likely to differ from the five city average, while those in Milan and Naples were most likely to welcome films that audiences elsewhere in Italy rejected. These statistics are broadly consistent with the findings of the correlation analysis reported in Table 4, which showed a high degree of correlation between Rome and other cities, with lower levels of correlation in the other pairings.

\section{[Table 9 here]}

When we bring these two lines of enquiry together and examine the nationalities of the most variable films, with the cities in which these films were most popular, some quite striking differences emerge. Table 9 shows a fairly clear north-south divide. The southern cities of Naples and Bari were ones in which the clear majority of films that held a distinctive local appeal were domestic Italian productions. The northern cities of Milan and Turin, on the other hand, were ones in which audiences seldom showed any particularly local preference for domestic films, but where they were much more likely to be won over by certain international productions that failed to generate a popular response in other parts of the country. 
Before exploring the significance of these findings in closer detail, it is worth returning to the distinction referred to in our introduction between vertical and horizontal differentiation of cultural products. Horizontal differentiation involves the construction of categories (such as genres) that enable consumers to form a judgement about the nature of the product in question and its intended target audience. Vertical differentiation refers to the perceived 'quality' of such products in terms of the strength of their audience appeal. Within any given horizontal category some films will prove more popular than others. Some horizontally defined categories will be much narrower than others, so the most successful production in a specialist category may end up attracting a much smaller audience than a mediocre offering in a more mainstream field. For film, this means that across the market as a whole, indicators of vertical differentiation based on box-office appeal give a clear indication of a film's reach, but not necessarily of its perceived quality. Within carefully defined horizontal categories, however, vertical differentiation by box-office revenue offer a much stronger indication about perceived product quality.

How do local variations in audience taste play into these distinctions between horizontal and vertical differentiation? There are at least three ways in which we might think about local variations in these terms. First, we can imagine that some horizontally defined categories of film might have a stronger audience base in some locations than others, in which case we would expect to see the most popular films within such categories attracting a varied response. For instance, during the mid-1930s in industrial Bolton, England, the locally born star Gracie Fields was so popular with audiences that the films in which she appeared 
topped the listings, contrasting strongly with the performance of her films in the South of England. ${ }^{33}$ If we follow this point to its logical conclusion we arrive at our second possibility, which is that certain horizontal categories of film might emerge specifically in response to consumer demand in a particular location. In this sense, local cultural identity itself forms the basis of a specific category of film. Andrew Higson has shown that this phenomena is well understood at the national level but is less often discussed at the sub-national level. ${ }^{34}$ Was there, for example, a category of films being produced in Italy that was specifically intended to capture a southern Italian (or more specifically a Neapolitan) sense of culture and identity? The third possibility is simply that audiences in certain locations would occasionally reach an a typical collective judgement about the 'quality' of any given film, and thus provide it with an unusually high or low vertical ranking. In the first two cases, local variations in consumption patterns can be explained and, to a lesser extent, predicted. In the third case local variations are far more random, and add another dimension to what Richard Caves calls the 'nobody knows' principle.

Looking at the films that received the most variable response within Italy during our period, it would seem that all three factors might have been in play. In the northern Italian cities, and in Milan in particular, we find a prevalence of European films among those that received a distinctively strong reception. Some of these were older films being given a national re-release (such as $M$, and Kind Hearts and Coronets); others included The Seventh Seal, Tom Jones, Ballad of a Soldier and Hiroshima Mon Amour. While it would be difficult to group these films together into a single genre category, we might nonetheless think of them as part 
of a horizontal grouping likely to appeal to an internationally minded and cosmopolitan audience. Thought of in these terms, it may not be surprising that such films did much better in Milan than in most other Italian cities. This is not to say, of course, that there were not cosmopolitan audiences in other Italian cities too, but that the size of this audience segment in Milan was likely to have been much larger.

In the case of the southern cities of Naples and Bari, it is striking just how many domestically produced films were among those receiving an unusually strong local reception. This does beg the question whether the Italian producers of these films were intending to appeal primarily to a local rather than a national audience. In the case of the international films that went down so well in Milan or Turin, it is hard to imagine that northern Italian audiences were the primary target market that directors such as Ingmar Bergman or Tony Richardson, or their producers, had in mind when making their films. It is much more likely that there happened to be a much larger market for the films of leading European directors in Milan than in other parts of Italy. But was it also the case that Neapolitan audiences just happened to prefer certain types of domestic Italian film, or were domestic Italian producers actively producing films for Neapolitan audiences?

Whichever method we employ for identifying the 100 films with the most varied local reception, we find that 18 of them (Table 9) were solo domestic Italian productions that proved unusually popular in Naples. The majority of these films (12 or 13 depending on the selection method employed) starred the Neapolitan 
comic actor Totò often appearing alongside fellow Neapolitan Peppino De Filippo. Most of these films featured the lead actor's name very prominently in the title (e.g. Totò, Peppino e la Dolce Vita, Totò e Peppino Divisi a Berlino, Totò Diabolicus), clearly indicating that these films belonged to an identifiable series (or horizontal category). A further five Totò films also appeared on the list of films that were particularly popular in Bari. Indeed, so partial were these films to the audiences of both cities that in their absence the number of Italian films on the list of the 100 most variably received films would be no more than those emanating from Hollywood.

\section{[Table 10 here]}

Table 10 provides information on the 28 Totò films released during seven seasons 1957-8 and 1963-4 and illustrates that while not among the hits of their day, with RelPOP scores varying around the median, they were consistently more warmly received in the two cities of the South than in Rome, Milan or Turin. Interestingly, Totò seems to have understood his worth, moving between studios - 16 studios were responsible for these 28 films - according to his latest biographer, in pursuit of earnings. He is quoted as saying:

"Today I get a lot of contracts, a lot of money and tomorrow? Nobody knows. Maybe tomorrow the audience is no more interested in my movies or the producers do not trust me anymore. What could I do? Back to the theatre as an old man? No, it's better to make everything now, to take every single opportunity, as long as it lasts." (Governi, 2017) 
By way of contrast, the much smaller comedy series built around the feuding relations between Catholic priest Don Camillo (played by the French comic actor Fernandel) and Communist mayor Peppone (Gino Cervi), further illustrates this point about regional loyalties. This time set in a small agricultural community in the Po Valley, the two films listed in Table 10, along with three others made outside of the period of this investigation, attracted strong positive audience responses in Turin and Milan but for audiences in Rome, Naples and Bari their appeal was muted..$^{35}$

The American films in our lists of the most variable films are far harder to categorise. Those popular in the north included a handful of Tom and Jerry films, along with Operation Petticoat and Elmer Gantry (Milan) and My Man Godfrey and Imitation General (Turin). Those proving unusually popular in the south included Flower Drum Song and Madam X (Naples) and The Big Fisherman and Happy Road (Bari). These films do not appear to belong to any discernible horizontal category. They are all examples of what we might loosely describe as mainstream Hollywood entertainment, for which there was a receptive market throughout Italy. None were major hits, but in each case we see that audiences in one of our five cities responded particularly strongly, (vertically) ranking them much more highly than audiences elsewhere.

\section{Discussion and conclusion}

Film and cultural historians have emphasised the role that cinemagoing played in maintaining a sense of social identity at a local and regional level in the midtwentieth century. ${ }^{36}$ For Forgacs and Gundle (2007), cinema contributed to 
process of drawing Italians '...en masse into the collective life of their nation and were attributed importance in shaping its destiny.'37 Prior to the widespread adoption of television, the cinema often served as a neighbourhood focal point around which local communities would cohere. Here, audiences might collectively embrace the glamour and spectacle of the latest Hollywood entertainment, but equally they could reject content that failed to resonate with their desires, beliefs and ideals. These local dynamics of cinemagoing, however, have seldom been incorporated into economic analyses of the film industry - in part because of the limited availability of directly comparable local data sources. A more detailed and nuanced picture of film markets at a sub-national level, however, is important if we are to understand the extent to which heterogeneity is a factor in consumer taste for cultural products and how, in the instance of the film industry, these are catered for.

Previous studies have identified local or regional variations in film taste, but usually in relation to the reception of foreign (i.e. American) films within specific national markets. Examinations of film audiences in the 1930s in various countries have suggested that domestic productions fared better metropolitan centres, while American films were more warmly received in the provinces or suburbs. $^{38}$ There have been fewer attempts to explore regional variations in the reception of domestically produced films within national markets, and thus of the extent to which film-makers sought to exploit regional, as well as national, cinema markets. Our evidence about the regional specificity of the audience for Toto films in Italy in the 1960s, rather like that for the films of Gracie Fields in 
Britain in the 1930s, suggests that these regional differences could indeed be important in helping to shape film culture.'

This article has examined the Italian market for films during a period in which the economy was growing at an unprecedented rate but nevertheless where the North-South divide was still pronounced. Based on regional city data collected by the exhibitors association (AGIS), it has been possible to identify both those films that were commonly popular across the country and also highlight variations in the appeal of some films in different parts of the country? It is clear that the latter were not the major blockbuster hits that captured the largest share of the market. We needed to delve deeper than the annual box-office top ten to locate such films.

What our analysis shows, we suggest, is that among the films that had a highly uneven reception in Italy were a mixture of curiosities (which we make no real attempt to explain) along with others that constituted a distinct category of film production in their own right. The existence of an observable category of films that consistently elicited strong local/regional responses would imply strongly that such films were deliberately targeted at a local rather than a national market. Both types of films have something to teach us about the functioning of the Italian film industry.

To deal with the historical curiosities first, the important point about such films is precisely that the variability of their local reception was so unpredictable. We 
may never know why It Started With A Kiss, starring Glenn Ford and Debbie Reynolds, failed in Milan while attracting good business in Naples, nor why the opposite was true of Ask Any Girl, featuring David Niven and Shirley Maclaine. Such cases serve as a reminder that local audiences could, and did, respond in unpredictable ways to individual films, and that these responses cannot easily be attributed to the level of promotional support provided in different locations. The two films referred to above were both distributed by MGM throughout Italy in the same year. While differences in film choice between national markets are often influenced by film policy and the protectionist support offered to local productions, such features are less evident when it comes to local differences within national markets. What we appear to see here are quite genuine (and unpredictable) differences in consumer preferences, which the system of film exhibition within Italy was able to quickly recognise and respond to accordingly.

The existence of a body of films that appeared to be targeted at specific local or regional audiences suggests that some local differences in taste were more predictable than others. The enduring series of Totò films constituted a recognisable category of productions that were horizontally differentiated from other products in the market. Yet this was a category of films that consistently failed to generate significant popular appeal in major cities such as Rome, Milan or Turin. Their appeal was largely restricted to southern Italy, where they consistently attracted strong audiences. Such films illustrate that within this national film market it was possible to identify (and exploit) entrepreneurial opportunities on the basis of local variations in consumer demand. 
Drawing upon the conceptual distinction between the vertical and horizontal differentiation of films, it seems clear that films are differentiated in many ways in the minds of audiences and that for different films different factors predominate. Sometimes regional variations in demand are predictable and sometimes they are not. The strong positive reaction to the films of Totò in Naples in the 1950s and 60s, in contrast to the indifference shown by audiences in Rome, Milan and Turin, was certainly a consistent (and predictable) pattern.

That such a pattern was able to develop, however, tells us something important about the adaptability of the film industry. It draws attention to the existence of distinctive local preferences, which were an integral feature of cinema culture during this period. It also illustrates that extent to which film producers were attracted by content that had a high likelihood of achieving a genuinely popular appeal (even if only on a regional basis). In an industry as riven with uncertainty as film production, any sign of a predictable and reliable market for a particular category of films constituted an important opportunity (provided production budgets could be controlled accordingly). Where such markets were uncovered, they could form the basis of sustainable film production activities, even if only on a limited scale. Just as 'national' cinema production was able to survive and flourish alongside the more internationally oriented output of Hollywood, so (if we look hard enough) we can find evidence of 'regional' films that were able to serve a valuable function within heterogeneous national cinema markets. 


\section{References}

\section{Trade Publications}

AGIS, Annuario del cinema italiano, Rome (published from 1951)

AGIS, Giornale dello spettacolo: Settimanale d'informazione delle attività economiche, tecniche, artistiche e sindacali dello spettacolo, Rome (published from 1957)

Journal articles and books

Beath, J., and Katsoulacos, Y., The Economic Theory of Product Differentiation, Cambridge, UK: Cambridge University Press, 1991

G. Bakker, 'Selling French films on Foreign Markets: The International Strategy of a Medium-Sized Company', Enterprise and Society, 5 (2004): 45-76

Bakker, G., Entertainment Industrialised: the Emergence of the international Film Industry, 1890-1940, Cambridge UK: Cambridge University Press, 2008

Browning, H., and Sorrell, A., 'Cinema and cinema-going in Great Britain', Journal of the Royal Statistical Society, 117 (1954): 133-165

Caves, R., Creative Industries: Contacts between Art and Commerce, Cambridge, Mass.: Harvard University Press, 2000

De Vany, A., and Walls, W., 'Bose-Einstein Dynamics and Adaptive Contracting in the Motion Picture Industry', Economic Journal 106 (1996) pp. 1493-1514 
Felice E., 'Regional value added in Italy, 1891-2001, and the foundation of a long- term RelPOPcture', The Economic History Review, 64 (2011): 929-950

Felice, E., and Vecchi, G., 'Italy's Modern Economic Growth, 1861-2011', Enterprise and Society, 16 (2015): 225-248

Forgacs, D., and Gundle, S., Mass Culture and Italian Society: From Fascism to the Cold War, (Bloomington, University of Indiana Press, 2007)

Garncarz, J., Wechselnde vorlieben, (Frankfurt am Main: Stroemfeld, 2015)

Governi, G., Totò. Vita opere e miracoli, Roma,Fazi Editore, 2017.

Handel, L. Hollywood Looks at its Audience, Urbana, Ill.: University of Illinois Press, 1950

Higson, A. Waving the Flag: Constructing a National Cinema in Britain, Oxford: Oxford University Press, 1995

Hoskins, Colin, Stuart McFadyen, and Adam Finn, Global Television and Film: An Introduction to the Economics of the Business, Oxford: Clarendon, 1997

Jarvie, I., Hollywood's overseas campaign: the North Atlantic movie trade, 1920-1950, Cambridge: Cambridge University Press, 1992 
Johanson, Jan, and Jan-Erik Vahlne. 'The Uppsala Internationalization Process

Model Revisited: From Liability of Foreignness to Liability of Outsidership.

Journal of International Business Studies, 40, no. 9 (2009): 1411-1431

Kuhn, A., 'An Everyday Magic: Cinema and Cultural Memory', London, I.B. Tauris, 2002

Kuisel, R., Seducing the French: the Dilemma of Americanization, Berkeley:

University of California Press, 1993

Miskell, P., A Social History of Cinema in Wales: PulRelPOPts, CoalRelPOPts and FleaRelPOPts Cardiff: University of Wales Press, 2006.

Miskell, P., (2016) International Films and International Markets: the

Globalisation of Hollywood Entertainment, C.1921-1951, Media History, 22, no.

$2,174-200$

Miskell, P., and Nicoli, M., 'From Outsiders to Insiders? Strategies and Practices of American Film Distributors in Postwar Italy', Enterprise and Society,

Vol. 17, No. 3 (2016), pp. 546-590

Richards, J. and Sheridan, D., Mass Observation at the Movies, London: Routledge, 1987 
Scarpellini, E., Material Nation: A Consumer's History of Modern Italy, (Oxford, Oxford University Press, 2008)

Scott, A. J., 'Hollywood and the world: the geography of motion-RelPOPcture distribution and marketing', Review of International Political Economy, 11, 1, (February 2004), pp. 33-61.

Sedgwick, J., Popular Filmgoing in 1930s Britain: a Choice of Pleasures, (Exeter: Exeter University Press, 2000).

Sedgwick, J., 'Product Differentiation at the Movies: Hollywood, 1946-65', Journal of Economic History', 62 (2002), pp. 676-704

Sedgwick, J. and Pokorny, M., 'The film business in the U.S. and Britain during the 1930s', Economic History Review, 58, (2005) pp. 79-112

Sedgwick, J., and Nicoli, M. 'Popular filmgoing in mid-1950s Milan: opening up the 'black box", in Biltereyst, D., Maltby, R. \& Meers, Ph. (eds.) Routledge Companion to New Cinema History, (New York, Routledge, in press/2018).

Sedgwick, J., and Pokorny, M., 'Hollywood's Foreign Earnings During the 1930s', Transnational Cinemas', 1 (2010): 83-97 
Sedgwick, J., Pafort-Overduin, C. and Boter, J. 'Explanations for the restrained development of the Dutch cinema market in the 1930s, Enterprise and Society, 13 (2012): 634-671

Sedgwick, J., Pokorny, M. and Miskell, P., 'Hollywood in the world market evidence from Australia in the mid-1930s', Business History, 56 (2014): 689-723

Thompson, D., Hit Makers: How Things Become Popular, London: Allen Lane, 2017.

Thompson, K. Exporting Entertainment: America in the World Film Market London, BFI, 1985.

Treveri Gennari, D., Post-War Italian Cinema: American Intervention, Vatican Interests, New York: Routledge, 2009.

Treveri Gennari, D., “'If you have seen it, you cannot forget!” Film consumption and memories of cinema-going in 1950s Rome,' Historical Journal of Film Radio and Television, 35 (2015): 53-74

Treveri Gennari, D., and Sedgwick, J. 'Memories in context: the social and economic function of cinema in 1950s Rome', Film History, 27, 2 (2015), pp.76104 
Trumpbour, J. Selling Hollywood to the World: U.S. and Europe Struggles for Mastery of the Global Film Industry, 1920-1950, Cambridge: Cambridge University Press, 2002.

Ulff-Møller, J., Hollywood's 'Film Wars' with France: Film-Trade Diplomacy and the Emergence of a French Film Quota Policy, Rochester, NY: University of Rochester Press, 2001.

Vasey, R., The world according to Hollywood, 1918-1939, Exeter University Press: Exeter, 1997.

Zaheer, Srilata. "Overcoming the Liability of Foreignness." The Academy of Management Journal 38, no. 2 (1995): 341-3 


\section{End Notes}

${ }^{1}$ Scott, Hollywood, 56-7

2 Jarvie, Hollywood's, 1992; Ulff-Møller, Hollywood's, 2001; Trumpbour, Selling, 2002; Vasey, World, 1997

3 Thompson, Exporting, 1985

${ }^{4}$ Bakker, Entertainment, 2008

5 Miskell, International, 2016

${ }^{6}$ Sedgwick and Pokorny, Hollywood's, 2010

${ }^{7}$ Bakker, Selling, 2004, pp. 50-53

${ }^{8}$ Miskell and Nicoli, Outsiders, 2016, Sedgwick, Filmgoing, 2000; Sedgwick, Pafort-Overduin and Boter, Explanations, 2012; Sedgwick, Pokorny and Miskell, Hollywood, 2014; Treveri Gennari and Sedgwick, Memories, 2015

${ }^{9}$ Garncarz, Wechselnde, 2015; Kuisel, Seducing, 1993

${ }^{10}$ Hoskins, McFadyen and Finn, Global, 1997; Zaheer, Overcoming, 1995; Johanson and Vahlne, Uppsala, 2009

11 Trumpbour, Selling, 2002; Richards and Sheridan, Mass Observation, 1987; Sedgwick, Pokorny and Miskell, Hollywood, 2014

12 Beath and Katsoulacos, Economic, 1991; Sedgwick, Product, 2002

13 Caves, Creative, 2000

${ }^{14}$ De Vany and Walls, Bose-Einstein, 1996; Sedgwick and Pokorny, Film, 2005

15 Felice, Regional, 2011; Felice and Vecchi, Italy's, 2015

16 Miskell and Nicoli, Outsiders, 2016

${ }^{17}$ See http://timeseries.istat.it - Table 8.6, Italian Historical Statistical Repository

18 Scarpellini, Material, 2008, p.133

19 Browning and Sorrell, Cinema, 1954

20 Those between CEIAD-Columbia and Dear-United Artists

${ }^{21}$ Miskell and Nicoli, Outsiders, 2016

22 Annuario, 1967

${ }^{23}$ See for example Alessandro Ferraù, "Un anno di prime visioni”, in Borsa Film n.41, August 1, 1959

${ }^{24}$ Felice and Vecchi, Italy's, 2015, p. 236

${ }^{25}$ See Table 2, Treveri Gennari and Sedgwick, Memories, 2015, for details of cinema statistics for 13 Italian cities in 1956

26 De Vany and Walls, Bose-Einstein, 1996

27 Sedgwick and Pokorny, Film, 2005

28 Thompson, Hit-makers, 2017

${ }^{29}$ Sedgwick and Nicoli, Popular, 2017; Gennari and Sedgwick, Memories, 2015

30 This should be contrasted with the POPSTAT Index that Sedgwick (2000) developed to measure absolute film popularity, in the absence of box-office records.

${ }^{31}$ It is the RelPOP of each film (actual box-office/median box-office) in each city during the year of release that is correlated in turn with the other cities.

${ }^{32}$ Handel, Hollywood, 1950

33 Sedgwick, Filmgoing, 2000

34 Higson, Waving, 1995

35 The three were: Don Camillo (1952); I ritorno di Don Camillo (1953); and Don Camillo e l'onorevole Peppone (1955)

36 Kuhn, Everyday, 2002; Miskell, Social, 2006; Treveri Gennari, Film Consumption, 2015

${ }^{37}$ Forgacs and Gundle, Mass Culture, 2007, p.274

38 As in fn. 11 